Al IbTIDA 3 (2): 291-304
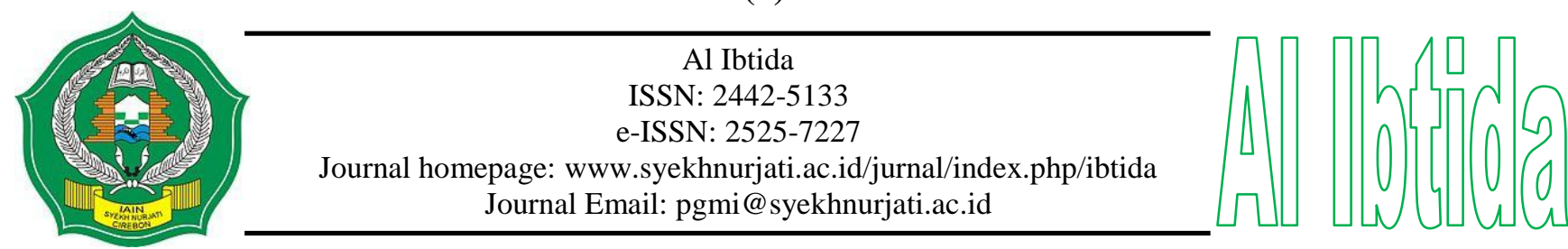

\title{
PERBANDINGAN KEMAMPUAN MEMBACA PERMULAAN ANTARA SISWA KELAS I MELALUI TK DENGAN TIDAK MELALUI TK DI MI PGM KOTA CIREBON
}

\author{
Ai Sabrina* \\ *Jurusan PGMI, Fakultas Ilmu Tarbiyah dan Keguruan, IAIN Syekh Nurjati Cirebon \\ Email: aisabrina94@gmail.com \\ Idah Faridah Laily* \\ *Jurusan PGMI, Fakultas Ilmu Tarbiyah dan Keguruan, IAIN Syekh Nurjati Cirebon \\ Email: idahfaridahlaily@yahoo.com
}

\begin{abstract}
Abstrak
Berdasarkan temuan penulis pada studi pendahuluan di MI Persatuan Guru Madrasah (PGM) Kota Cirebon ditemukan bahwa dalam pelaksanaan proses belajar membaca permulaan terdapat perbedaan kemampuan membaca yang signifikan antara siswa yang sebelumnya menempuh pendidikan di Taman kana-Kanak (TK) dengan siswa siswi yang tidak menempuh Pendidikan Taman Kanak-Kanak (TK), baik dari kefasihan ataupun dari kelancaran membaca. Kemampuan membaca permulaan merupakan proses mengenal bacaan yang dilakukan secara terprogram yang diperuntukkan untuk anak usia dini. Siswa melalui TK pada kemampuan membaca sudah mengenal simbol huruf, mengucapkan bunyi huruf, membedakan huruf, menyebutkan benda, memahami hubungan bunyi dan huruf dan melafalkan kata dengan jelas. Sedangkan siswa tidak melalui TK secara keseluruhan belum mengenal kegiatan dan kurikulum yang diajarkan pada siswa yang melalui TK.

Penelitian ini menggunakan penelitian kuantitatif kasual komparasi. Teknik pengumpulan data meliputi tes dan observasi. Populasi dalam penelitian adalah seluruh siswa kelas I (satu) MI PGM Kota Cirebon. Dengan teknik Boring Sampling, sampel yang diambil adalah siswa kelas I A dan I B yang jumlahnya adalah 64 siswa. Setelah data diperoleh, data tersebut kemudian dianalisis dengan menggunakan uji T (Independent Sample test) data yang diperoleh berdistribusi normal. Hasil penelitian ini menjunjukkan bahwa terdapat $98 \%$ siswa lulusan tk tuntas belajar dan yang belum tuntas $2 \%$. Sedangkan pada non tk $10 \%$ yang tuntas dan yang belum tuntas terdapat $90 \%$.
\end{abstract}

Kata Kunci: Kemampuan Membaca, Melalui TK, Tidak Melalui TK 


\begin{abstract}
Based on researcher findings in introduction study at MI PGM Cirebon. The researcher found to apply process of reading learning in introduction, there is constrast difference in reading ability between kindergarden and non-kindergarden students., the difference is based on reading fluency. Ability in introduction reading is a process to know reading that happen programmed for children. In kindergarden, reading ability students have known alphabet symbol, how to say sounds of alphabet, how to distinguish alphabet, mention noun, how to understand the relation between sound and alphabet and pronounce word clearly. Meanwhile, students that non-kindergarden overall have not known activities and curriculum used in kindergarden.

This research use quantitative casual comparation. Technic of collecting the data by using test and observation. Population in this research is all students in first grade MI PGM Cirebon. Researcher use boring sampling that take a sample from first grade A and B. Total of the students number is 64 students. After obtain the data, researcher analyze by using $T$ experiment (independent sample test), the data obtained normal distributed. The result showed that there is about 98\% students graduation from kindergarden have achieved minimal score, only $2 \%$ students are not achieved. Besides, nonkindergarden only about 10\% students are achieved minimal score and there are $90 \%$ students are not achieved minimal score.
\end{abstract}

Keywords: Reading Skill, Kindergarden, Non-Kindergarden

\title{
PENDAHULUAN
}

Kemampuan membaca permulaan merupakan kegiatan membaca yang diajarkan pada anak yang baru masuk sekolah dasar sebelum ia mengenal huruf atau bacaan. Apabila di sekolah, siswa tidak memiliki kemampuan membaca, maka akan mengalami kesulitan untuk mata pelajaran yang lain. Kurikulum SD 1994 menekankan bahwa tujuan pembelajaran membaca di Sekolah Dasar dibagi ke dalam dua golongan, yakni pertama agar siswa menguasai teknik membaca, dan kedua agar siswa dapat memahami isi bacaan. Tujuan pertama dapat dicapai melalui pembelajaran membaca permulaan, dan tujuan yang kedua dapat melalui pembelajaran membaca pemahaman (Dekdikbud dalam Somadayo, 2011: 6).

Kemampuan membaca di Sekolah Dasar merupakan sebagai bekal dasar untuk menguasai berbagai mata pelajaran. Apabila anak pada usia sekolah permulaan tidak segera memiliki kemampuan membaca, maka siswa tersebut ketika naik pada tingkat selanjutnya akan mengalami banyak kesulitan. Oleh sebab itu, anak harus memiliki kemampuan membaca permulaan agar ketika menginjak pada kelas berikutnya sudah memiliki bekal dasar dan bisa memasuki pada kemampuan membaca pemahaman. 
Nuttall dalam Yunus (2012: 13) mengemukakan bahwa pembelajaran membaca harus dilakukan dengan tujuan membangun kemampuan membaca anak. Hal ini berarti pembelajaran membaca tidak bisa dilakukan secara sporadis melainkan harus dilakukan secara bertahap. Beberapa tahapan dalam pembelajaran membaca tersebut adalah: 1) memberanikan anak membaca; 2) mendorong anak membaca; 3) menjajaki kemampuan baca anak agar mengetahui kelemahan anak dalam membaca; 4) modeling membacA: mendemonstrasikan cara-cara yang dibutuhkan anak dalam membaca; dan 5) klarifikasi: memberikan contoh baca, menjelaskan strategi membaca dan memberikan pembelajaran secara eksplisit jika diperlukan.

Membaca permulaan ini mecakup: (1) pengenalan bentuk huruf; (2) pengenalan unsur-unsur linguistik; (3) pengenalan hubungan/korespondensi pola ejaan dan bunyi (kemampuan menyuarakan bahan tertulis); dan (4) kecepatan membaca bertaraf lambat (Dalman, 2013:85).

Erickson (Calvin S. Hall dan Gardner Lindzeny, 1993: 167) (dalam Syamsu, 2011: 47) mengemukakan bahwa "masa kanak-kanak merupakan gambaran manusia sebagai manusia, perilaku yang berkelainan pada masa dewasa dapat dideteksi pada masa kanak-kanak". Usia dini merupakan perkembangan dan pertumbuhan yang sangat menentukan perkembangan masa selanjutnya. Berbagai studi yang dilakukan para ahli menyimpulkan bahwa pendidikan anak sejak dini dapat memperbaiki prestasi dan meningkatkan produktivitas kerjamasa dewasanya.

Pada umumnya anak yang telah menempuh pendidikan taman kanak-kanak pada proses membacanya lebih baik dibandingkan dengan anak yang tidak menempuh pendidikan taman kanak-kanak. Karena anak yang menempuh pendidikan taman kanak-kanak sudah dikenalkan pada symbol huruf, dan berbagai pengetahuan dasar untuk anak usia dini sudah disosialisasikan pada jenjang taman kanak-kanak. Sehingga kesiapan belajar pada anak sudah ada ketika anak tersebut memasuki jenjang sekolah dasar.

Berdasarkan penelitian awal di MI PGM Kota Cirebon ditemukan bahwa, dalam pelaksanaan proses belajar membaca permulaan terdapat perbedaan kemampuan membaca permulaan antara siswa siswi yang sebelumnya menempuh pendidikan di Taman kanaKanak (TK) dengan siswa siswi yang tidak menempuh Pendidikan Taman Kanak-Kanak (TK), baik dari kefasihan ataupun dari kelancaran membaca. Berdasarkan dari masalah ini penulis ingin mencoba mengangkat judul "PERBANDINGAN KEMAMPUAN MEMBACA PERMULAAN ANTARA SISWA KELAS I MELALUI TK DENGAN TIDAK MELAUI TK DI MI PGM KOTA CIREBON”. 


\section{METODE PENELITIAN}

Desain penelitian yang penulis gunakan adalah desain dasar penelitian kasual komparatif yang sederhana, dan walaupun variabel bebas tidak dimanipulasi, ada prosedur kontrol yang dapat diterapkan. Statistik inferensial yang paling umum digunakan adalah uji t yang digunakan untuk melihat apakah terdapat suatu perbedaan yang siginifikan antara ratarata dari dua kelompok. Uji chi-kuadrat yang digunakan untuk membandingkan frekuensifrekuensi kelompok, yaitu untuk melihat apakah suatu kejadian sering muncul dalam satu kelompok daripada kelompok lain. (Emzir, 2007: 130).

Tabel 1. Desain Penelitian

\begin{tabular}{|c|c|c|c|}
\hline \multirow{2}{*}{ Sampel } & \multicolumn{2}{|c|}{ Frekuensi Pada } & \multirow{2}{*}{ Jumlah Sampel } \\
\cline { 2 - 3 } & Objek I & Objek II & \\
\hline Sampel A & A & B & $\mathrm{a}+\mathrm{b}$ \\
\hline Sampel B & C & D & $\mathrm{c}+\mathrm{d}$ \\
\hline Jumlah & $\mathrm{a}+\mathrm{c}$ & $\mathrm{b}+\mathrm{d}$ & $\mathrm{N}$ \\
\hline
\end{tabular}

Sumber (Hasan, 2009:131)

Keterangan:

Sampel A = Sampel pertama kemampuan membaca permulaan siswa melalui TK (X)

Sampel B = Sampel kedua kemampuan membaca permulaan siswa tidak melalui TK (Y)

abcd = Data nominal berbentuk frekuensi

$\mathrm{n}=$ Jumlah

Populasi dalam penelitian ini adalah kelas I A dan I B MI PGM Kota Cirebon yang seluruhnya berjumlah 64 siswa. Kelas I A terdiri dari 32 siswa dan Kelas I B terdiri dari 32 siswa. Peneliti memilih kelas I untuk dijadikan populasi penelitian dengan asumsi kemampuan membaca permulaan berada di kelas I (satu). Teknik pengambilan sampel dalam penelitian ini adalah sampel jenuh yaitu sampel yang mewakili jumlah populasi. Hal ini sering dilakukan bila jumlah populasi relatif kecil, penelitian yang ingin membuat generalisasi dengan kesalahan yang sangat kecil (Sugiyono, 2016: 85). Teknik ini dipilih karena yang menjadi populasi dalam penelitian ini jumlahnya kurang dari 100, maka semua populasi dijadikan sampel penelitian. Dengan demikian jelaslah bahwa yang menjadi sampel dalam penelitian ini jumlahnya 64 siswa.

Teknik pengumpulan data dalam penelitian ini penulis menggunakan lembar tes dan lembar observasi untuk memperoleh data pada perbandingan kemampuan membaca siswa 
melalui TK dengan tidak melalui TK. Instrumen tes kemampuan membaca permulaan yang digunakan dalam penelitian ini berupa tes suku kata dan membaca kalimat sederhana. Tes dilaksanakan sebelum dan sesudah perlakuan (treatment). Siswa akan diberi kata dan kalimat yang sederhana, umumnya yang mudah-mudah dan berhubungan dengan diri siswa yang sudah dikenal. Kalimat-kalimat itu ditulis dengan huruf-huruf tulis, yang tiap-tiap dapat diulanginya. Tes kemampuan membaca permulaan digunakan sebagai alat pengumpul data untuk mengetahui hasil kemampuan membaca siswa antara melalui TK dengan tidak melalui TK.

Sementara itu, lembar observasi dalam penelitian ini sebagai alat pengumpul data, dibuat untuk mengamati kegiatan belajar mengajar siswa dan guru. Pengamatan terhadap siswa difokuskan pada saat siswa mengikuti proses pembelajaran Bahasa Indonesia dalam kemampuan membaca permulaan. Instrumen pengumpulan data yang digunakan dalam penelitian ini adalah lembar observasi dengan menggunakan Skala aspek penilaian membaca disusun peneliti berdasarkan komponen kognitif. Masing-masing terdiri dari 10 item dengan empat pilihan jawaban yaitu sangat baik, baik, dan kurang Skor 3, 2, dan 1 yaitu salah satu alat observasi yang ditujukan untuk memperoleh data yang ingin diamati oleh peneliti di mana dalam pelaksanaan di lapangan tinggal memberi angka pada kolom (Wulan, 2013). Berikut tabel instrumen aspek penilaian membaca permulaan:

Tabel 2. Aspek Penilaian Membaca Permulaan

\begin{tabular}{|c|c|c|c|c|c|c|c|c|}
\hline \multirow[b]{2}{*}{ No } & \multirow{2}{*}{$\begin{array}{c}\text { Nama } \\
\text { Siswa } \\
\text { Kelas } 1\end{array}$} & \multicolumn{3}{|c|}{ Aspek yang dinilai } & \multirow{2}{*}{$\begin{array}{c}\text { Skor } \\
\text { maks } \\
9\end{array}$} & \multirow[b]{2}{*}{ Nilai } & \multicolumn{2}{|c|}{ Ket } \\
\hline & & $\begin{array}{c}\text { Mengena } \\
1 \text { Simbol } \\
\text { (huruf) }\end{array}$ & $\begin{array}{c}\text { Mengenal } \\
\text { Kata }\end{array}$ & $\begin{array}{l}\text { Kelancaran } \\
\text { membaca }\end{array}$ & & & $\mathrm{T}$ & TT \\
\hline 1 & $\begin{array}{c}\text { Alfiza } \\
\text { Nuryadi }\end{array}$ & 3 & 3 & 3 & 9 & 100 & $\mathrm{~T}$ & \\
\hline 2 & $\begin{array}{c}\text { Annisa } \\
\text { Nurjannah }\end{array}$ & 3 & 2 & 2 & 8 & 88,9 & $\mathrm{~T}$ & \\
\hline 3 & $\begin{array}{c}\text { Indira } \\
\text { Aprilioni }\end{array}$ & 2 & 2 & 1 & 5 & 55,6 & & TT \\
\hline
\end{tabular}

(Wulan, 2013)

Keterangan : $\mathrm{T}=$ Tuntas

TT $=$ Tidak Tuntas

Teknik analisis data dalam penelitian ini dilakukan melalui pendekatan kuantitatif. Analisis data kuantitatif diperoleh dari data hasil tes dan observasi yang dilakukan terhadap siswa dan guru pada kemampuan membaca permulaan. Data yang didapatkan ditampilkan dalam bentuk angka. 
Uji Normalitas

Untuk menguji kenormalan suatu data digambarkan rumus Chi-Kuadrat (Emzir, 2007:133).

$$
X^{2}=\sum_{i=1}^{k} \frac{(O i-E i)^{2}}{E i}
$$

Keterangan :

$\mathrm{Oi}=$ Frekeunsi Pengamatan

$\mathrm{Ei}=$ Frekuensi Harapan

Uji Homogenitas

Uji Homogenitas digunakan sebagai bahan acuan untuk menentukan keputusan uji statistik. Adapun rumus pengambilan keputusan dalam uji homogenitas adalah (Istiarini, 2012).

Uji Hipotesis

$$
\begin{aligned}
& F_{\text {hitung }}=\frac{\text { Varians terbesar }}{\text { Varians terkecil }} \\
& \text { keterangan }: \\
& F=\text { Homogenitas dua varians } \\
& V b=\text { Varians terbesar } \\
& V k=\text { Varians terkecil }
\end{aligned}
$$

Uji hipotesis dilakukan untuk membuktikan ada atau tidaknya perbedaan kemampuan membaca permulaan antara siswa melalui TK dengan siswa tidak melalui TK. Apabila data itu berdistribusi normal maka dilakukan statistik parametis dan sebaliknya jika data itu tidak berdistribusi normal maka dilakukan statistik nonparamestris. Untuk uji hipotesis ini penulis menggunakan uji-test dengan rumus (Istiarini, 2012).

$$
\text { Thitung }=\frac{X_{1=X_{2}}}{\sqrt{\frac{s 1^{2}}{B_{1}}+\frac{s 2^{2}}{B_{2}} 2, r\left(\frac{s 1}{\sqrt{n_{1}}}\right)+\left(\frac{s 2}{\sqrt{n_{2}}}\right)}}
$$

Keterangan :

$$
\begin{array}{ll}
\mathrm{r} & =\text { Nilai korelasi } \mathrm{X}_{1} \text { dengan } \mathrm{X}_{2} \\
n_{1} \text { dan } n_{21}= & \text { Jumlah sampel } \\
X_{1} & \text { Nilai rata-rata perbedaan kemampuan membaca } \\
& \text { permulaan siswa yang melalui TK } \\
X_{2} & \text { Nilai rata-rata perbedaan kemampuan membaca } \\
& \text { permulaan siswa yang tidak melalui TK } \\
= & \text { Standar Deviasi kemampuan membaca permulaan } \\
S_{1} & \text { siswa melalui TK } \\
= & \text { Standar Deviasi kemampuan membaca permulaan } \\
& \text { Siswa tidak melalui TK } \\
S_{2} & =\text { Varians sampel melalui TK } \\
S_{1}^{2} & \text { Varians sampel tidak melalui TK } \\
S_{1}^{2} &
\end{array}
$$


Disesuaikan dengan kriteria hipotesis sebagai berikut :

- Jika to $\geq \mathrm{t}$ - table maka Ha diterima dan Ho ditolak

- Jika to $\leq \mathrm{t}$-tabel maka Ha ditolak dan Ho diterima

$\mathrm{db}=\left(N_{1}+N_{2}-2\right)$ dengan taraf signifikasi sebesar $\mathrm{a}=0,05$

\section{HASIL DAN PEMBAHASAN}

Hasil Kemampuan Membaca Permulaan Siswa melalui TK

Tabel 3. Statistics

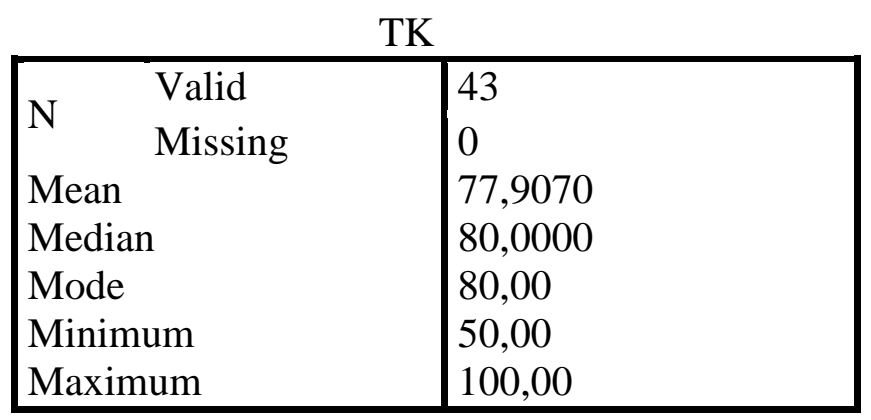

Mean atau rata-rata Kemampuan membaca TK sebesar 77,91. Median diperoleh 80, Mode didapat 80 sementara nilai minimal dan maksimal masing-masing sebesar 50 dan 100 . Berikut grafik Kemampuan membaca TK:

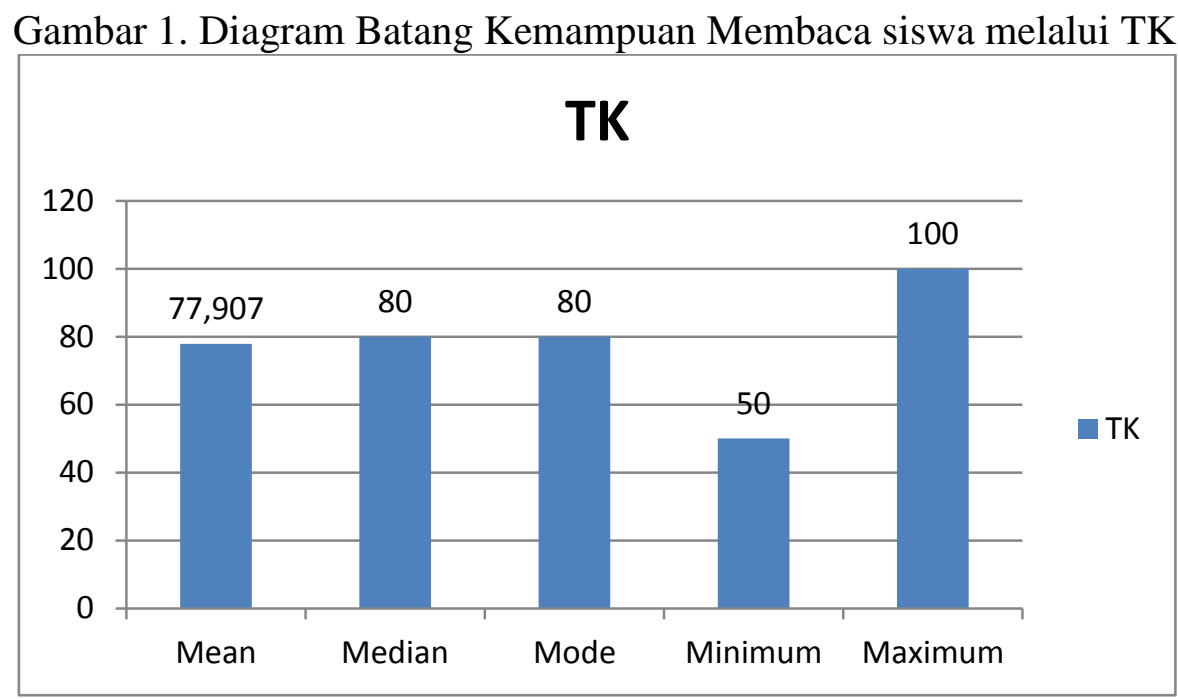

Berdasarkan gambar diagram batang diatas, menunjukkan bahwa Mean atau rata-rata Kemampuan membaca TK sebesar 77,91. Median diperoleh 80, Mode didapat 80 sementara nilai minimal dan maksimal masing-masing sebesar 50 dan 100. Dapat dikatakan bahwa siswa yang melalui TK terhadap kemampuan membaca permulaan kriterinya baik, karena siswa melalui TK sudah dikenalkan beragam kemampuan membaca permulaan sebelum memasuki jenjang pendidikan dasar. 


\section{Hasil Kemampuan Membaca Permulaan siswa tidak melalui TK}

Tabel 4. Statistics

Non TK

\begin{tabular}{|l|l|}
\hline $\mathrm{N} \quad$ Valid & 21 \\
Mean & 0 \\
Median & 40,4762 \\
Mode & 40,0000 \\
Minimum & 40,00 \\
Maximum & 30,00 \\
\hline
\end{tabular}

Berdasakan table statistics di atas jumlah responden sebanyak 21 siswa. Missing 0 menunjukkan bahwa data yang hilang adalah nol, dengan demikian tidak ada data yang belum diproses.

Mean atau rata-rata Kemampuan membaca non TK sebesar 40,4762. Median diperoleh 40, Mode didapat 40 sementara nilai minimal dan maksimal masing-masing sebesar 30 dan 60. Berikut grafik Kemampuan membaca non TK:

Gambar 2. Diagram Batang Kemmpuan Membaca siswa tidak melalui TK

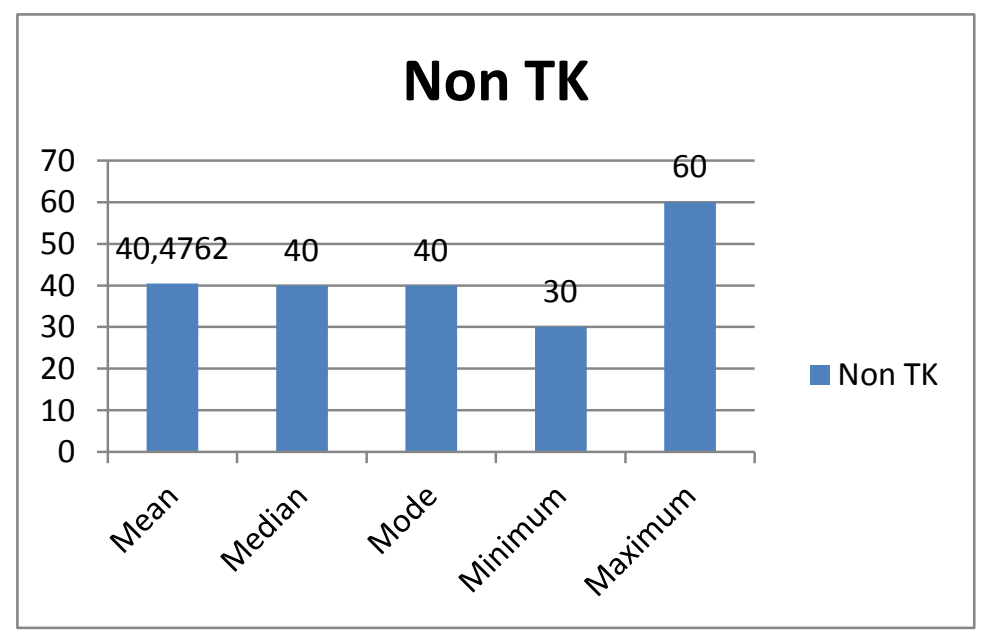

Berdasarkan diagram batang diatas, bahwa Mean atau rata-rata Kemampuan membaca non TK sebesar 40,4762. Median diperoleh 40, Mode didapat 40 sementara nilai minimal dan maksimal masing-masing sebesar 30 dan 60. Hal ini disebabkan siswa yang tidak melalui TK mengenal beragam bahasa secara keselurah, seperti mengenal simbol huruf, kata, menyusun kata menjadi kalimat dan menyuarakan simbol bahasa sesuai dengan lafal dan intonasi yang sesuai. Sehingga dapat dikatakan bahwa siswa yang tidak melalui TK terhadap kemampuan membaca permulaan kriterianya masih kurang. 


\section{Perbandingan Kemampuan Membaca Permulaan Antara Siswa Melalui TK dengan \\ Siswa Tidak Melalui TK}

Diperoleh data hasil analisis kemampuan membaca antara siswa kelas I yang melalui TK dengan tidak melalui TK. Berikut tabel perbedaan kemampuan membaca siswa TK dengan siswa Non TK:

Tabel 5.

Perbandingan Kemampuan Membaca Permulaan Antara Siswa melalui TK dengan Siswa tidak melaluiTK

\begin{tabular}{|c|c|c|c|c|}
\hline \multirow{2}{*}{ Tingkatan } & \multicolumn{2}{|c|}{ Tuntas } & \multicolumn{2}{c|}{ Belum Tuntas } \\
\cline { 2 - 5 } & Frekuensi & Presentase & Frekuensi & Presentase \\
\hline TK & 42 & $98 \%$ & 1 & $2 \%$ \\
\hline Non TK & 2 & $10 \%$ & 19 & $90 \%$ \\
\hline
\end{tabular}

Berdasarkan tabel di atas antara tabel kemampuan membaca siswa TK dengan Siswa Non TK dapat disimpulkan bahwa kemampuan membaca permulaan dari hasil analisis menunjukkan terdapat $98 \%$ siswa melalui TK tuntas belajar dan yang belum tuntas $2 \%$ dengan frekuensi siswa melalui TK yang tuntas sejumlah 42 siswa sedangkan yang tidak tuntas hanya 1 siswa. Sedangkan pada non tk 10\% yang tuntas dan yang belum tuntas terdapat $90 \%$ dengan frekuensi siswa Non TK yang tuntas hanya 2 siswa sementara itu yang tidak tuntas sejumlah 19 siswa. Berikut grafiknya.

Gambar 3. Diagram Batang Perbandingan Kemampuan Membaca Permulaan Siswa TK dengan Siswa Non TK

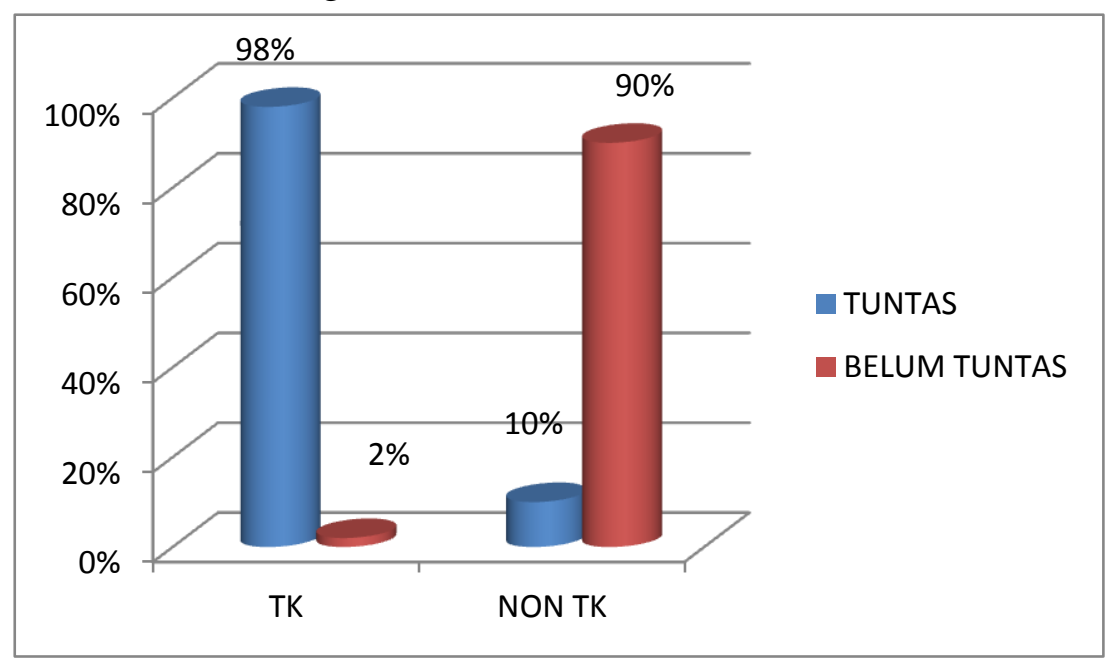

Berdasarkan gambar diagram di atas, dapat dilihat bahwa kemampuan membaca siswa melalui TK dalam ketuntasan aspek membacanya sangat baik sebesar 98\%, namun siswa yang melalui TK dalam ketuntatasan aspek membaca hanya $2 \%$. Sedangkan siswa yang tidak melalui TK yang tuntas dalam aspek membaca hanya $10 \%$, semntara itu yang 
tidak tuntas sebesar 90\%. Disini dapat disimpulkan bahwa kemampuan membaca siswa yang melalui TK lebih baik karena siswa yang melalui TK sudah dikenalkan mengenai simbol tulisan(huruf), kata, serta mampu menyuarakan lambang bahasa sehingga kemampuan membacanya lebih baik dari siswa yang tidak melalui TK.

\section{Uji Normalitas}

Uji normalitas dilakukan untuk mengetahui apakah data berdistribusi normal ataut idak. Pada pembahasan ini, uji normalitas dilakukan dengan uji Kolmogorov-Smirnov dengan kriteria sebagai berikut :

a. Hipotesis Statistik

Ho : Data berdistribusi normal

Ha : Data tidak berdistribusi normal

b. Kriteria pengambilan pengujian yaitu :

Dengan melihat angka probabilitas atau signifikan, dengan ketentuan :

Signifikan> 0,05 maka Ho diterima

Signifikan< 0,05 maka Ho ditolak

\section{Tabel 6. One-Sample Kolmogorov-Smirnov Test}

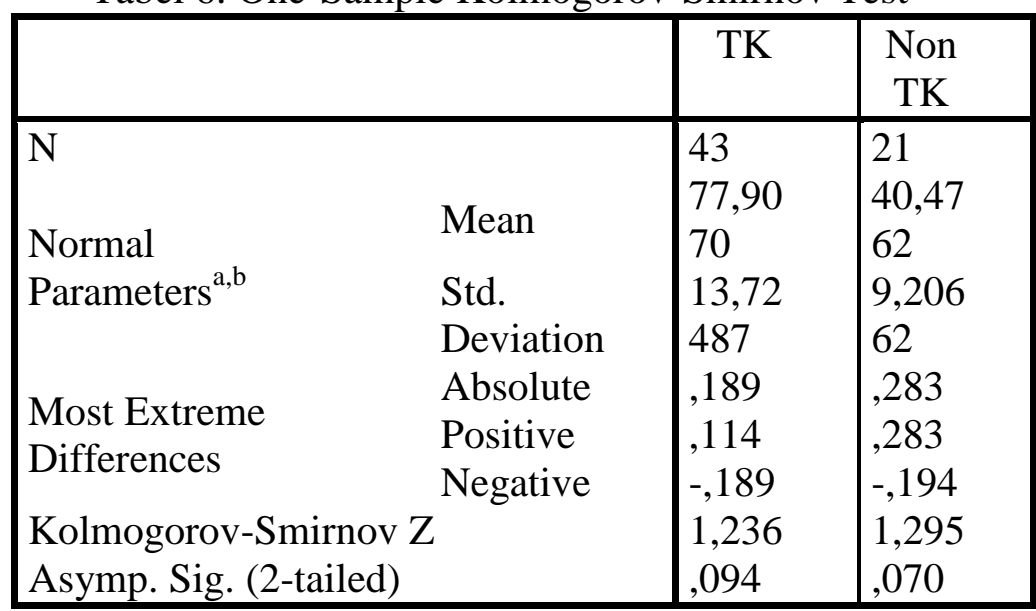

a. Test distribution is Normal.

b. Calculated from data.

Hasil uji normalitas pada tabel test of normality data kemampuan membaca permulaan TK menunjukkan nilai signifikan pada uji kolmogorov sebesar 0,094. Dan data kemampuan membaca permulaan non TK menunjukkan nilai signifikan pada uji kolmogorov sebesar 0,070. Karena nilai tersebut signifikan berada di atas 0,05. Maka data kemampuan membaca permulaan TK dan non TK berdistribusi normal. 


\section{Uji Homogenitas}

Uji homogenitas dilakukan untuk mengetahui kesamaan antara keadaan atau populasi. Untuk menguji Homogenitas kedua sampel dilakukan dengan menganalisa Varians masing-masing dari data. Berikut adalah hasil dari uji homogenitas yang dilakukan:

Tabel 7. Test of Homogeneity of Variances

Kemampuan Membaca Permulaan

\begin{tabular}{|r|r|r|l|}
\hline Levene Statistic & df1 & df2 & Sig. \\
\hline 5,151 & 1 & 62 &, 027 \\
\hline
\end{tabular}

Tabel hasil uji homogenitas Lavene Test di atas, menunjukan tingkat signifikansi atau nilai probabilitas berada di bawah 0,05 , maka dengan demikian $\mathrm{H}_{0}$ diterima, artinya data tersebut tidak homogeny.

\section{Uji T (Independent Sample test)}

Sehubungan asumsi normalitas data kemampuan membaca permulaan TK dan non TK terpenuhi, maka selanjutnya untuk melihat perbedaan dua rata-rata nilai data kemampuan membaca permulaan TK dan non TK dilakukan pengujian Independent Sample test.

Hipotesis untuk pengujian ini dirumuskan sebagai berikut :

$\mathrm{H}_{0}$ : Tidak terdapat perbedaan kemampuan membaca permulaan antara siswa kelas I melalui TK dengan tidak melalui TK di MI PGM Kota Cirebon

$\mathrm{H}_{1}$ : Terdapat perbedaan kemampuan membaca permulaan antara siswa kelas I melalui TK dengan tidak melalui TK di MI PGM Kota Cirebon

Berdasarkan analisis kemampuan membaca siswa TK dengan Siswa Non TK dapat disimpulkan bahwa kemampuan membaca permulaan dari hasil analisis menunjukkan terdapat $98 \%$ siswa melalui TK tuntas belajar dan yang belum tuntas $2 \%$ dengan frekuensi siswa melalui TK yang tuntas sejumlah 42 siswa sedangkan yang tidak tuntas hanya 1 siswa. Sedangkan pada non tk $10 \%$ yang tuntas dan yang belum tuntas terdapat $90 \%$ dengan frekuensi siswa Non TK yang tuntas hanya 2 siswa sementara itu yang tidak tuntas sejumlah 19 siswa. Berikut grafiknya.

Dari hasil uji normalitas pada kemampuan membaca permulaan TK menunjukkan nilai signifikan pada uji kolmogorov sebesar 0,094. Dan data kemampuan membaca 
permulaan non TK menunjukkan nilai signifikan pada uji kolmogorov sebesar 0,070. Karena tersebut nilai signifikan berada di atas 0,05. Maka data kemampuan membaca

Permulaan melalui TK dan tidak melalui TK berdistribusi normal. Tabel hasil uji homogenitas Lavene Test di atas, menunjukan tingkat signifikansi atau nilai probabilitas berada di bawah 0,05, maka dengan demikian $\mathrm{H}_{0}$ diterima, artinya data tersebut tidak homogeny. Tabel hasil uji homogenitas Lavene Test menunjukan tingkat signifikansi atau nilai probabilitas berada di bawah 0,05 , maka dengandemikian $\mathrm{H}_{0}$ diterima, artinya data tersebuttidak homogeny. Hasil analisis pada aspek kemampuan membaca permulaan menunjukkan terdapat $98 \%$ siswa melalui TK tuntas belajar dan yang belum tuntas $2 \%$. Sedangkan pada non tk $10 \%$ yang tuntas dan yang belum tuntas terdapat $90 \%$.

Berdasarkanhasiluji Independent Sample test di atas nilai signifikan sebesar 0,000. Karena nilai signifikan lebih kecil dari 0,05 dan t hitung $(12,902)$ lebih besar dari t tabel $(1,999)$ maka Ho ditolak, artinya Terdapat perbedaan kemampuan membaca permulaan antara siswa kelas I melalui TK dengan tidak melalui TK di MI PGM Kota Cirebon.

Perbandingan antara siswa melalui pendidikan taman kanak-kanak dengan siswa yang tidak melalui pendidikan akan memiliki perbedaan terhadap kemampuan membaca permulaan. Siswa yang menempuh pendidikan di taman kanak-kanak telah dikenalkan berbagai kemampuan bahasa seperti menulis, membaca dan menghitung. Sedangkan siswa yang tidak menempuh pendidikan TK belum mengenal simbol bahasa tulis/kemampuan membaca dan menulis. Karena pendidikan sejak dini merupakan suatu hal yang diinginkan para orang tua agar ketika memasuki jenjang sekolah dasar anak mereka sudah dibekali dengan kemampuan bahasa, seperti membaca dan menulis.

Pada umumnya siswa yang pernah masuk Taman Kanak-kanak kemampuan membacanya lebih baik dibandingkan dengansiswa yang tidak dari Taman Kanak-kanak. Penyebabnya karena kesiapan belajar membaca, pengenalan huruf dan sosialisasi antara anak lebih baik dar isiswa yang tidak dari Taman Kanak-kanak

Berdasarkan pengamatan peneliti dilapangan perbedaan kemampuan membaca permulaan kelas I antara siswa melalui TK dengan siswa tidak melalui TK ada perbedaan yang cukup signifikan. Siswa yang menempuh pendidikan Taman Kanak-kanak sudah mengenal simbol bahasa, menulis, menyuarakan simbol bahasa yang sesuai dengan intonasi serta lafal yang benar, membedakan huruf kecil dan huruf kapital, membedakan huruf vokal dan huruf konsonan, mengenal kata serta memiliki keterampilan menulis dan membaca cerita. Sedangkan siswa yang tidak menempuh pendidikan di Taman Kanak-kanak rata-rata belum memiliki beragam keterampilan seperti siswa yang menempuh jenjang pendidikan 
Taman Kanak-kanak. Hanya ada beberapa saja siswa yang memiliki kemampuan mengenal simbol bahasa, menyuarakan simbol bahasa, menulis dan membaca namun jumlahnya relatif kecil.

Membaca permulaan menekankan pengkondisian anak untuk masuk dan mengenal bacaan sehingga belum sampai pada pemahaman yang mendalam pada materi bacaan. Membaca permulaan adalah suatu kesatuan kegiatan yang terpadu mencakup beberapa kegiatan seperti mengenali huruf dan kata-kata, menghubungkannya dengan bunyi, maknanya, serta menarik kesimpulan mengenai maksud bacaan.

Di lembaga pendidikan anak usia dini, anak-anak sudah diajarkan dasar-dasar cara belajar. Tentunya di usia dini, mereka akan belajar fondasi-fondasinya. Di lembaga pendidikan anak usia dini yang bagus, anak-anak belajar menjadi cepat beradaptasi dan semangat untuk belajar.

Usia dini/prasekolah merupakan kesempatan emas bagi anak untuk belajar. Oleh karena itu, kesempatan ini hendaknya dimanfaatkan sebaik-baiknya untuk pembelajaran anak karena rasa ingin tahu anak usia ini berada pada posisi puncak. Tidak ada usia sesudahnya yang menyimpan rasa ingin tahu anak melebihi usia dini. Satu hal yang perlu mendapatkan perhatian, bahwa orientasi belajar anak usia dini bukan terfokus pada prestasi, seperti kemampuan membaca, menulis, berhitung dan penguasaan pengetahuan lain yang bersifat akademis, tetapi belajarnya perlu lebih diarahkan pada pengembangan pribadi, seperti sikap dan minat belajar serta berbagai potensi dan kemampuan dasarnya.

Adapun tujuan lain dari membaca permulaan adalah untuk membangkitkan, membina dan memupuk minat anak untuk membaca. Siswa sekolah dasar harus mampu membaca dengan tepat. Ketepatan membaca permulaan sangat dipengaruhi oleh keaktifan dan kreatifitas guru yang mengajar dikelas I SD. Keberhasilan belajar siswa dalammengikuti proses kegiatan belajar mengajar ditentukan oleh penguasaan kemampuan membaca mereka. Banyak pakar pendidikan mencari solusi bagaimana cara memperbaiki pembelajaran kemampuan membaca permulaan.

Pembelajaran membaca permulaan pada jenjang sekolah dasar harus memperoleh perhatian yang sungguh-sungguh dari pendidik. Baik itu siswa yang menempuh pendidikan taman kanak-kanak atau tidak dari pendidikan taman kanak-kanak. Karena membaca merupakan salah satu jenis kemampuan berbahasa tulis yang bersifat reseptif. Disebut reseptif karena dengan membaca seseorang akan mendapat memperoleh informasi, memperoleh ilmu dan pengetahuan, serta pengalaman-pengalaman baru. Oleh sabab itu, pembelajaran membaca di sekolah dasar mempunyai peranan penting. 


\section{DAFTAR PUSTAKA}

Dalman. (2013). KeterampilanMembaca. Depok: Raja Grafindo Persada.

Emzir. (2014) Metode Penelitian Pendidikan. Jakarta: Raja Grafindo Persada

Hasan, Iqbal. (2009) Analisis Data Penelitian dengan Statistik. Jakarta: Bumi Aksara

Istiarini, R. (2012). Jurnal Pendidikan Akuntasi Indonesia.http://journal.uny.ac.id/ article/viewfile.pdf. (Diakses pada tanggal 05 Agustus 2016 Pukul 20:10 WIB)

Jihad dan Haris.( 2013) Evaluasi Pembelajaran. Yogyakarta: Multi Pressindo

Nazir, Mohammad. (2005) Metode Penelitian. Bogor: Ghalia Indonesia Aksara

Sugiyono. (2016) Metode Penelitian Kuantitatif, Kualitatif dan R\&D. Bandung: Alfabeta

Syamsu Yusuf \& Nani M. Sugandhi. (2011) Perkembangan PesertaDidik. Jakarta: Raja Grafindo Persada.

Wulan, Ratna. 2013. Peranan Intelegensi, Penguasaan Kosakata,Sikap, dan Minat terhadap Kemampuan Membaca padaAnak. http://jounral.uny.ac.id/ article/download. (Diakses pada_tanggal 03 Agustus 2016 Pukul 11:35 WIB) 